\title{
PEMENUHAN NAFKAH MUT'AH, IDDAH, DAN MADIYAH ISTRI SEBAGAI SYARAT PENJATUHAN TALAK DALAM PERADILAN AGAMA DI INDONESIA
}

\author{
Syaiful Hidayat \\ Institut Agama Islam Bani Fattah Jombang, Indonesia \\ Email: Abynenina@yahoo.com
}

\begin{abstract}
In the concept of procedural law in Indonesia, when the verdict has been handed down and divorce has been dropped, the husband is obliged to fulfill his ex-wife's livelihood rights, but in reality the problem arises namely the assumption that after the divorce occurs there is no more thing that needs to be done by the husband, including giving a living to his ex-wife and child after the divorce. The law has arranged a solution for that, namely by the process of execution, but because the execution costs are too expensive compared to the amount of income that is not much, then the community fails to make the request for execution. This is the reason for the policy carried out by the Religious Court.
\end{abstract}

Keywords: Living Divorce Wife, Religious Court

\section{Pendahuluan}

Perkawinan merupakan gabungan antara ibadah serta muamalah, dengan begitu dalam sebuah perkawinan berlaku kedua prinsip tersebut. Prinsip dasar dalam ibadah sendiri adalah pengabdian total kepada Allah SWT, sedangkan prinsip dasar muamalah adalah kesepakatan serta keridlaan kedua belah pihak yang terlibat.

Dalam Kompilasi Hukum Islam dijelaskan bahwa perkawinan merupakan sebuah ikatan lahir batin yang sangat agung antara suami dan istri (mîthâqan ghâlidan) untuk mentaati perintah Allah dan melaksanakannya merupakan ibadah. ${ }^{1}$ Sedangkan tujuan perkawinan sendiri adalah untuk mewujudkan sebuah keluarga yang sakinah, mawaddah dan rahmah sebagai salah satu sarana ibadah kepada Allah

${ }^{1}$ Kompilasi Hukum Islam, Pasal II.

Tafáqquh: Jurnal Penelitian dan Kajian Keislaman Volume 6, Nomor 2, Desember 2018; p-ISSN 2338-3186; e-ISSN 2549-1873; 181-195 
SWT. ${ }^{2}$ Selain itu, dalam Undang-Undang Perkawinan juga dijelaskan bahwa Perkawinan adalah ikatan lahir batin antara seorang laki-laki dengan seorang wanita sebagai suami istri dengan tujuan untuk membentuk keluarga (rumah tangga) yang bahagia dan kekal berdasarkan Ketuhanan Yang Maha Esa. ${ }^{3}$

Di samping itu, perkawinan juga merupakan sunnah Rasul yang pernah dilakukannya selama hidupnya dan menghendaki umatnya berbuat yang sama. ${ }^{4} \mathrm{Hal}$ ini terdapat dalam hadis yang berasal dari Anas bin Malik, sabda Nabi yang bunyinya:

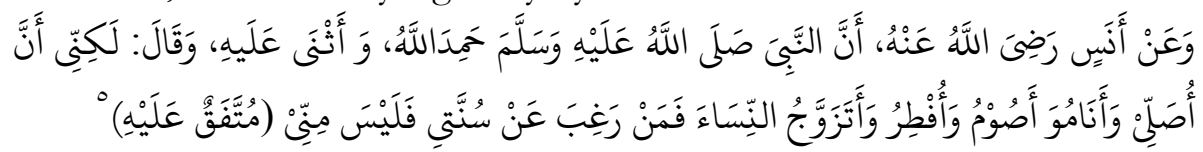

Artinya: "Dari Anas Ibnu Malik Radbiyallâbu 'anbu babwa Nabi Sallallabu 'alaibi wa sallam, setelah memuji dan Allah dan menyanjung-Nya bersabda: "Tetapi aku sholat, tidur, berpuasa, berbuka, dan mengawini perempuan. Barangsiapa membenci sunnabku, ia tidak termasuk. umatku."

Dengan adanya penjelasan mengenai perkawinan yang merupakan salah satu sunnah Rasul, maka seharusnya kita sebagai hamba Allah dan umat Rasul menjaganya dengan tidak mencacat atas apa yang dimaksudkan dari perkawinan itu sendiri. Yaitu tujuan untuk membentuk keluarga dalam rumah tangga yang bahagia, sakinah, mawaddah, dan rahmah.

Demi keberhasilan mewujudkan tujuan di atas, sangat diperlukan adanya kerbersamaan dan kerjasama antara suami istri dalam menjalankan perkawinannya. namun dalam kenyataannya tidak jarang ditemui percekcokan serta perselisihan antara suami istri, meskipun pada dasarnya mereka menginginkan dan mengupayakan persamaan pendapat, tetapi tidak menutup kemungkinan diantara suami istri terdapat perbedaan sifat, watak, serta pandangan hidup yang berbeda. Terkadang karena satu hal dapat terjadi masalah dan akhirnya menimbulkan pertentangan serta percekcokan antara suami dan istri, jika masalah yang timbul sudah berlarut-larut maka biasanya solusi terakhir yang akan ditempuh adalah perceraian.

\footnotetext{
${ }^{2}$ Kompilasi Hukum Islam, Pasal I-II.

3 Undang-Undang Republik Indonesia No. 1 Tabun 1974, Pasal II.

${ }^{4}$ Amir Syarifuddin, Hukum Perkawinan Islam di Indonesia: Antara Figh Munakahat dan UndangUndang Perkawinan (Jakarta: Prenada Media, 2006), 43.

5 Ibnu Hajar al-Asqalani, Bulughul Maram (Mesir: al-Matba'ah Salafiyyah, t.th) 195.
} 
Dalam Pengadilan Agama, dikenal dua bentuk perceraian yaitu cerai gugat dan cerai talak. Cerai gugat adalah sebuah gugatan permintaan cerai yang diajukan oleh istri kepada suami, sedangkan cerai talak adalah permohonan yang dilakukan suami kepada pengadilan untuk dapat dan atau diperbolehkan untuk menjatuhkan talak kepada istri dengan alasan yang telah diajukan sebelumnya.

Dalam hukum Islam sendiri sebenarnya putusnya perkawinan dalam bentuk talak dan khulu' tidak membutuhkan alasan sebagai syarat untuk terjadinya. Hal ini dikarenakan suami berkewajiban untuk membayarkan mahar dan memberikan nafkah kepada istri dengan demikian suami berhak mentalak istri tanpa ada alasan. Namun dalam konteks hukum positif di Indonesia hal ini tidak berlaku karena talak yang sah adalah yang dijatuhkan di depan sidang pengadilan dengan melalui pertimbangan oleh majelis hakim terhadap alasan-alasan dan bukti-bukti yang diajukan di persidangan.

Setelah terjadinya perceraian tentunya masalah tersebut belum selesai seperti halnya dengan perkawinan, dalam Kompilasi Hukum Islam disebutkan bahwa perceraian juga memiliki akibat hukum tersendiri apabila terjadi diantaranya: (a) memberikan mut'ah yang layak kepada bekas isterinya, baik berupa uang atau benda, kecuali bekas isteri tersebut qobla al-dukbûl; (b) memberi nafkah, maskan dan kiswah kepada bekas isteri selama dalam iddah, kecuali bekas isteri telah di jatuhi talak ba'in atau nushuz dan dalam keadaan tidak hamil; (c) melunasi mahar yang masih terhutang seluruhnya, dan separoh apabila qobla al-dukhîl; dan (d) memberikan biaya hadhanah untuk anak-anaknya yang belum mencapai umur 21 tahun. $^{6}$

Pemberian nafkah suami kepada istri yang telah ditalaknya dimaksudkan agar supaya istri yang telah ditalak dapat memenuhi segala kebutuhannya selama masa Iddah. Sebagaimana disebutkan dalam QS. al-Baqarâh ayat 241 sebagaimana berikut:

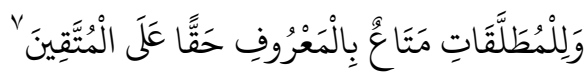

Artinya: "Kepada wanita-wanita yang diceraikan (bendaklah diberikan oleh suaminya) mut'ah menurut yang ma'ruf, sebagai suatu kewajiban bagi orang-orang yang bertaqwa."

${ }^{6}$ Kompilasi Hukum Islam, pasal 149.

${ }^{7}$ QS. al-Baqarâh: 241.

8 Yayasan Penyelenggara Penterjemah al-Qur'an DEPAG RI, Al-Qur'an dan Terjemahnya, 2: 241 
Ketika putusan telah ikrah dan talak telah dijatuhkan maka suami wajib untuk memenuhi hak-hak istrinya pasca perceraian, tetapi dalam realitanya muncul permasalahan yaitu anggapan masyarakat bahwa setelah perceraian terjadi maka sudah tidak ada hal yang perlu dilakukan oleh suami, termasuk melalaikan kewajibannya untuk memberi nafkah anak dan istrinya setelah perceraian. Inilah yang saat ini dihadapi oleh pengadilan agama bahwa banyaknya kasus penyelewengan hak yang dilakukan oleh suami setelah perceraian, meskipun Undang-undang telah mengatur solusi untuk itu yaitu dengan pengajuan eksekusi. Namun karena biaya eksekusi yang terlalu mahal maka masyarakat urung untuk melakukan gugatan eksekusi tersebut.

Dengan keadaan yang demikian, maka Pengadilan dalam hal ini majelis hakim memberikan sebuah alternatif solusi terbaik untuk menjamin terpenuhinya hak-hak istri pasca perceraian yaitu dengan melakukan penundaan sidang pembacaan ikrar talak sebelum hak istri dalam hal pemberian nafkah dilunasi. Solusi ini terpaksa dipilih meskipun bertentangan dengan asas peradilan agama yaitu peradilan dilakukan dengan sederhana, cepat, dan biaya ringan. ${ }^{9}$ Selain itu keputusan ini juga bertentangan dengan Kompilasi Hukum Islam pasal 149 dalam pasal ini dapat dipahami bahwa pemberian nafkah (mut'ah. iddah, dan madiyyah) terhadap istri pasca perceraian adalah karena sebab jatuhnya talak, bukan menjadi syarat jatuhnya talak.

Sebagai sebuah penelitian akademik, perlu dilakukan penelusuran terhadap penelitian ataupun literatur yang berkaitan dengan masalah yang sedang penulis teliti, salah satunya adalah naskah tulisan $\mathrm{H}$. Ahsin Abdul Hamid, seorang Hakim pada Pengadilan Tinggi Agama Jakarta. Dengan judul tulisan "Komentar Terhadap Amar Putusan PA Takalar", dalam tulisan ini $\mathrm{H}$. Ahsin mengkritisi kebijakan yang dilakukan oleh PA Takalar, dengan kesimpulan tidak sahnya putusan PA Takalar terkait pembayaran nafkah mantan istri sebelum adanya ikrar talak. ${ }^{10}$

Penelitian ini sendiri bersifat kualitatif, dengan pendekatan melalu studi lapangan dan studi pustaka, objek yang menjadi kajian penelitian adalah pemenuhan nafkah istri setelah perceraian di Pengadilan Agama.

\footnotetext{
${ }_{9}$ Undang-Undang No. 7 tabun 1989, pasal 57 ayat III

10 H. Ahsin Abdul Hamid, Komentar Terbadap Amar Putusan PA Takalar, dalam www.badilag.net diakses tanggal 07 April 2017
} 


\section{Pengertian nafkah Mut'ah, Iddah, dan Madiyah}

Mut'ah (المتعة) secara bahasa artinya adalah kesenangan, sedangkan menurut istilah yaitu sesuatu yang diberikan kepada istri yang dicerai sebagai penghibur. ${ }^{11}$ Pendapat lain mengatakan bahwa, makna mut'ah adalah:

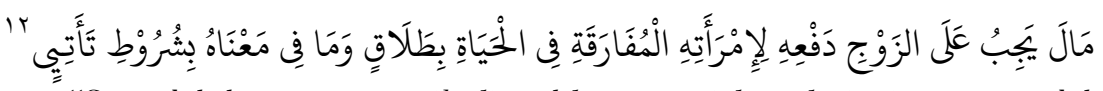

Artinya: "Sejumlah harta yang wajib diserabkan suami kepada istrinya yang telah diceraikannya semasa bidupnya dengan cara talak atau cara yang semakna dengannya."

Sebagian ulama fikih berpendapat bahwa mut'ah hanya disunnahkan, tidak diwajibkan, hal ini diperkuat oleh Imam Malik yang berpendapat bahwa perintah memberikan mut'ah itu sunnah. ${ }^{13}$ Imam Malik beralasan dengan firman Allah pada akhir ayat 236 surat al-Baqarâh:

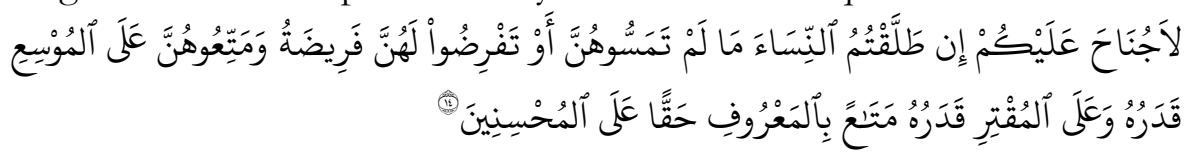

Artinya: "Tidak ada kewajiban membayar (mahar) atas kamu, jika kamu menceraikan istri-istri kamu sebelum kamu bercampur dengan mereka dan sebelum kamu menentukan maharnya. Dan bendaklah kamu berikan suatu mut'ab (pemberian) kepada mereka. Orang yang mampu menurut kemampuannya dan orang yang miskin menurut kemampuannya (pula), yaitu pemberian menurut yang patut. Yang demikian itu merupakan ketentuan bagi orang-orang yang berbuat kebajikan." 15

Imam Syafi'i berpendapat bahwa mut'ah diwajibkan untuk setiap istri yang dicerai ketika pemutusan perkawinan datang dari pihak suami, kecuali istri yang telah ditentukan maskawin untuknya dan dicerai sebelum digauli. Dalam qaul qadim, Imam Syafi'i berpendapat bahwa suami tidak wajib memberikan mut'ah kepada istri yang dicerainya, karena istri telah mendapat mahar. ${ }^{16}$ Sedangkan dalam qaul jadid, Imam Syafi'i berpendapat bahwa suami wajib memberikan mut'ah kepada istri yang dicerai, karena Allah berfirman dalam Q.S. al-Aḥzab ayat 28:

\footnotetext{
11 A.W. Munawwir, Kamus Al-Munawwir Arab-Indonesia (Surabaya: Pustaka Progresif, 1997), 1307.

${ }^{12}$ Muhammad al-Khathib al-Syarbayniy, Mughniy al-Mubtaj Juz 3 (Beirut: Dâr al-Ma'rifah, 1997.), 317

${ }^{13}$ Ibnu Rusyd, Bidayatul Mujtahid penerjemah: Imam Ghazali Said \& Achmad Zaidun, Vol. II (Jakarta : Pustaka Amani, 2002), 622.

${ }_{14}$ QS. al-Baqarâh ayat 241.

15 Al-Qur'an dan Terjemahnya, 2:241.

${ }^{16}$ Ibnu Rusyd, Bidayatul Mujtahid, 622.
}

185 Syaiful Hidayat - Pemenuhan Nafkah Mut'ah, Iddah, Dan Madlyah Istri Sebagai Syarat Penjatuhan Talak 


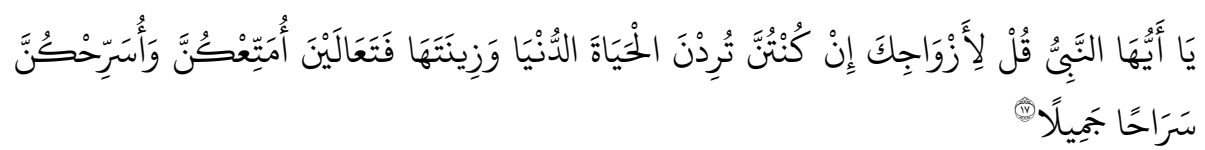

Artinya: "Wahai Nabi, katakanlah kepada istri-istrimu: jika kamu sekalian mengingini kehidupan dunia dan perbiasannya, maka marilah supaya kuberikan kepadamu mut'ah dan aku ceraikan kamu dengan cara yang baik." 18

Dalam qaul qadim tersebut, Imam Syafi'i menggunakan logika sebagai argumennya, sedangkan dalam qaul jadid, beliau menggunakan al-Qur'an sebagai argumennya. ${ }^{19}$ Selain itu menurut ulama fikih Ḍahiri berpendapat bahwa mut'ah wajib untuk setiap istri yang dicerai. ${ }^{20}$ Sesuai dengan firman Allah surat al-Baqarâh: 241, yang berbunyi:

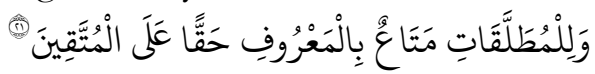

Artinya: "Kepada wanita-wanita yang diceraikan (bendaklah diberikan oleh suaminya) mut'ah menurut yang ma'ruf, sebagai suatu kewajiban bagi orang-orang yang bertakwa., 22

Sedangkan pengertian Iddah adalah, Iddah dalam bahasa Arab berasal dari akar kata 'adda-ya'uddu-'idatan dan jamaknya adalah 'idad yang secara arti kata berarti "menghitung" atau "hitungan". Kata ini digunakan dengan maksud bahwa dalam masa itu si perempuan yang telah bercerai sedang menunggu berlalunya waktu. ${ }^{23}$ Pendapat yang lebih lengkap tentang pengertian Iddah dikemukakan oleh Sayyid Sâbiq yaitu:

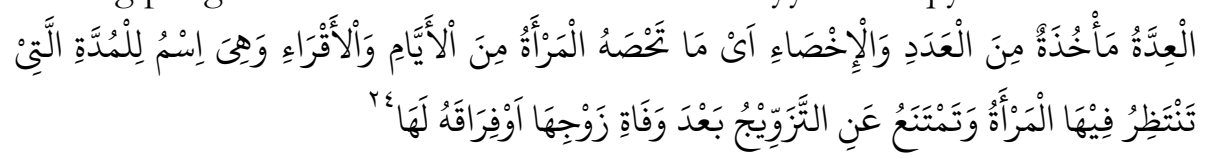

Artinya: "Iddah Ini adalah nama untuk periode dimana wanita menunggu dan menahan diri untuk tidak menikah setelah kematian suami mereka, atau setelah berpisabnya laki-laki darinya (perempuan)."

Lalu untuk lamanya seorang istri melakukan Iddah para ulama mazhab berbeda pendapat tentang berapa lama Iddah tersebut

\footnotetext{
${ }_{17}$ QS. al-Ahzâb ayat 28.

18 Al-Qur'an dan Terjemabnya 33:28.

19 Al-Syarbayniy, Mughniy, 241.

20 Al-Syarbayniy, Mughniy, 241.

${ }^{21}$ Q.S. al-Baqârah ayat 241.

22 Al-Qur'an dan Terjemabnya 2:241.

23 Prof. Dr. Amir Syarifuddin, Hukum Perkawinan Islam di Indonesia: Antara Fiqh Munakahat dan Undang-Undang Perkawinan (Jakarta: Prenada Media, 2006), Cet. III, 303.

${ }^{24}$ Sayyid Sâbiq, Fiqhu al-Sunnah Vol. 2 (Kairo: al-Fatḥ li al-A'lam al-'Arobiy, t.th.) 209.
} 
berlangsung, adapun dasar yang digunakan oleh para ulama mazhab adalah firman Allah dalam surat al-Baqarâh ayat 228:

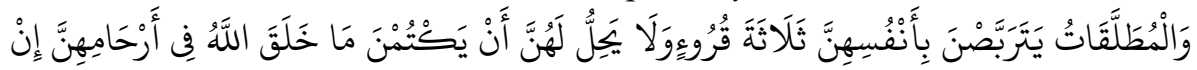

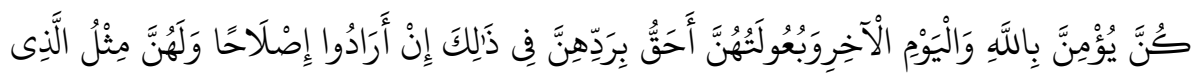

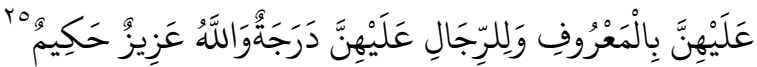

Artinya: "Wanita-wanita yang ditalak handaklah menahan diri (menunggu) tiga kali quru'. Tidak boleh mereka menyembunyikan apa yang diciptakan Allah dalam rabimnya, jika mereka beriman kepada Allab dan hari akbirat. Dan suami-suaminya berbak merujukinya dalam masa menanti itu, jikea mereka (para suami) menghendaki ishlah. Dan para wanita mempunyai bak yang seimbang dengan kewajibannya menurut cara yang ma'ruf. Akan tetapi para suami, mempunyai satu tingkatan kelebihan daripada istrinya. Dan Allah Maba Perkasa lagi Maha Bijaksana. ${ }^{, 26}$

Dari ayat inilah para ulama fikih berbeda pendapat mengenai arti kata quru'. Sekelompok ulama fikih berpendapat bahwa quru' adalah suci, yakni masa antara dua haid. Ulama mazhab yang setuju dengan pendapat ini diantaranya adalah Imam Malik dan Imam Syafi'i. sedangkan ulama mazhab yang berpendapat bahwa quru' adalah haid yaitu Abu Hanifah, Thauri, Auza'i, dan Ibnu Abi Laila. ${ }^{27}$ Perbedaan antara kedua pendapat tersebut adalah bagi mereka yang berpendapat bahwa quru' adalah suci maka apabila istri yang boleh dirujuk tersebut telah memasuki haid yang ketiga, maka suami tidak boleh merujuknya dan ia pun menjadi halal untuk diperistri oleh lelaki lain. Sedangkan apabila quru' adalah haid, maka menjadi halal untuk dinikahi oleh lelaki lain setelah melewati haid yang ketiga. ${ }^{28}$

Selanjutnya adalah jumlah nafkah Iddah, ulama sepakat bahwa jumlah pemberian nafkah iddah disamakan dengan jumlah nafkah yang biasa diberikan oleh suami ketika masih rukun. Akan tetapi para ulama berbeda pendapat mengenai ukuran standar dari nafkah tersebut. Menurut Imam Hanafi yang dijadikan standar nafkah adalah kebutuhan istri dengan tetap menyesuaikan kemampuan suaminya. ${ }^{29}$ Selanjutnya menurut Imam Syafi'i yang dijadikan sebagai standar ukuran nafkah istri adalah kemampuan ekonomi suaminya. ${ }^{30}$

\footnotetext{
${ }^{25}$ Al-Baqarâh ayat 228.

26 Departemen Agama RI, Al-Qur'an dan Terjemahnya..., 51.

27 Ibnu Rusyd, Bidayatul Mujtabid..., 602.

${ }^{28}$ Ibnu Rusyd, Bidayatul Mujtabid..., 602.

${ }^{29}$ Sayyid Sâbiq, Fiqbu al-Sunnah..., 114.

${ }^{30}$ Sayyid Sâbiq, Fiqbu al-Sunnah..., 115.
} 
Ulama Syafi'iyah juga memberikan rincian kewajiban suami pada tiga tingkatan. Pertama, bagi suami yang kaya kewajibannya adalah dua mud, 1 mud sama dengan satu kati atau 800 gram. Kedua, kewajiban suami yang miskin adalah satu mud.

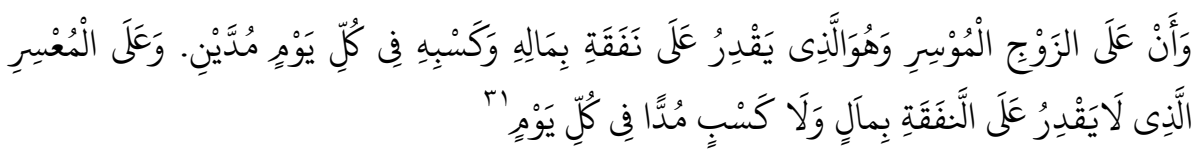

Artinya: "Dan bagi suami yang kaya wajib memberikan nafkah kepada istrinya dan dia mampu untuk menafkabi istrinya dengan bartanya dan pekerjaanya setiap harinya dua mud, sedangkan bagi suami yang miskin mampu untuk menafkahi istrinya dengan hartanya dan pekerjaanya wajib memberikan satu mud setiap harinya."

Yang terakhir adalah nafkah madiyah (lampau), merupakan nafkah terdahulu yang tidak atau belum ditunaikan oleh suami kepada istri sewaktu masih terikat perkawinan yang sah. Pengertian nafkah madiyah sendiri seperti diungkapkan Sayyid Sâbiq adalah:

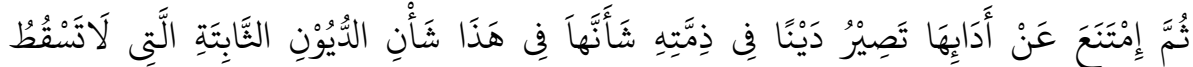

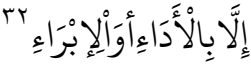

Artinya: "Dan ketika suami menahan untuk tidak memberikan nafkah kepada istrinya hal itu menjadi butang, butang ini akan tetap dan tidak akan putus kecuali telab dibayarkan atau dibebaskan."

Selain Sayyid Sâbiq, al-Sharbiyniy juga mengemukakan pengertian yang lain mengenai nafkah maḍiyah ini:

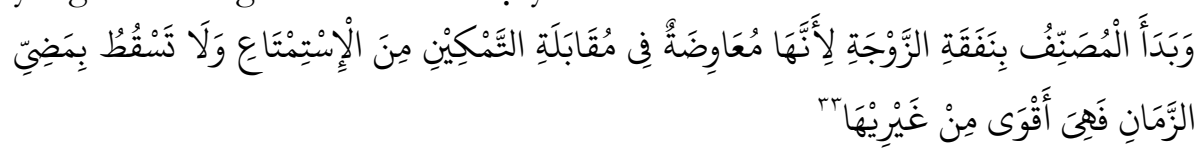

Artinya: "Dan pengarang kitab mendahulukan membahas nafkah sebab nafkah istri merupakan ganti dari kebolehan berbubungan badan, dan apabila waktu nafkah telab lewat, ini tidaklah memutus hak nafkah istri karena nafkeah ini lebih kuat dari lainnya."

Karena nafkah ini dianggap sebagai hutang, maka istri dapat menggugat suaminya ke Pengadilan Agama dengan gugatan nafkah madiyah atau nafkah yang belum ditunaikan oleh suami selama 3 (bulan) secara berturut-turut sebagaimana yang telah tercantum dalam sighat ta'like talaq.

\footnotetext{
${ }^{31}$ Sayyid Sabiq, Fiqhu al-Sunnah..., 115.

32 Sayyid Sâbiq, Fiqhu al-Sunnah Vol. 2 (Kairo: al-Fath li al-A'lam al-'Arabi, t.th), 1160

33 Al-Sharbiyniy, Mughniy al-Mubtaj Vol.3 (Bayrut: Dar al-Ma’rifah, 1997), 558.
} 


\section{Realisasi Pemenuhan Nafkah Mut'ah, Iddah dan Madiyah di Pengadilan Agama}

Setelah terjadinya perceraian maka mantan suami masih diwajibkan untuk memenuhi nafkah mantan istrinya antara lain adalah nafkah mutah, nafkah iddah, nafkah madidiah (lampau) dan mahar terhutang. Hal ini sesuai dengan yang dijelaskan dalam kitab-kitab fikih dan Undangundang No.1 Tahun 1974 serta Kompilasi Hukum Islam yang merupakan pedoman dasar dalam proses perceraian di Indonesia.

Dalam prakteknya di Pengadilan Agama, ketika sampai pada sidang pembuktian dan bahwa pasangan suami istri memang sudah tidak dapat untuk dipersatukan kembali, maka majelis hakim akan menjatuhkan putusan perceraian untuk memisahkan suami istri tersebut. Dalam kasus cerai talak atau perceraian karena kehendak suami, setelah pembacaan putusan, suami akan diminta oleh majelis hakim untuk memberikan nafkah-nafkah yang menjadi hak istri di atas sebelum suami membacakan ikrar talak di depan sidang Pengadilan. ${ }^{34}$

Apabila suami belum bisa membayar nafkah-nafkah istri di atas, maka majelis hakim akan melakukan penundaan pembacaan ikrar talak hingga paling lama 6 bulan, sedangkan apabila telah melampaui 6 bulan sang suami masih belum bisa membayar nafkah istrinya, dan istri masih bersikeras menuntut hak yang dimilikinya setelah perceraian. Maka putusan perceraian yang telah dikeluarkan oleh majelis hakim sebelumnya menjadi tidak dapat dilaksanakan (non excutabel) yang artinya putusan tersebut tidak dapat dijalankan dan pasangan suami istri tersebut masih merupakan pasangan suami istri yang sah serta perceraian tidak dapat diajukan lagi dengan alasan yang sama. ${ }^{35}$

Secara umum dalam proses perceraian di Pengadilan Agama Mojokerto, terdapat dua kebijakan yang dilakukan dalam rangka menjamin pemenuhan hak istri setelah terjadinya perceraian. Kebijakan tersebut adalah: Pertama, Pembayaran nafkah mantan istri sebelum pembacaan ikrar talak. Dalam melaksanakan pembayaran ini, suami dapat membayar secara langsung kepada mantan istri di depan sidang Pengadilan, atau apabila tidak memungkinkan dikarenakan beberapa hal, maka suami dapat menitipkan pembayaran nafkah istri kepada bagian administrasi pembayaran dengan mengisi SKUM (Surat Kuasa Untuk Membayar) sesuai dengan nominal yang disebutkan di dalam amar putusan majelis hakim.

\footnotetext{
${ }^{34}$ Drs. H. Mulyani, M.H., Hakim Pengadilan Agama Mojokerto.

35 Ibrahim Ahmad Harun S.Ag., Pedoman Pelaksanaan Tugas dan Administrasi Peradilan Agama Buku II (Jakarta: Mahkamah Agung RI, 2013), 48.
} 
Kedua, Penundaan pembacaan ikrar talak sampai 6 bulan, apabila mantan suami belum membayarkan nafkah mantan istri. Penundaan sidang ini dilakukan apabila suami belum bisa membayar sesuai dengan tanggal pembacaan ikrar talak yang disebutkan di dalam amar putusan, seperti disebutkan bahwa apabila suami belum mampu membayar maka pembacaan ikrar talak akan ditunda sampai dengan paling lama 6 bulan setelahnya, apabila sampai melewati batas waktu 6 bulan tersebut suami masih belum bisa menunaikan kewajibannya maka putusan yang telah dikeluarkan majelis hakim menjadi gugur.

Kebijakan-kebijakan tersebut tidak serta-merta ada, seperti dijelaskan dalam bab sebelumnya bahwa hakim memiliki alasan-alasan dalam memunculkan kebijakan pembayaran nafkah istri dan anak sebelum ikrar talak, dan penundaan ikrar untuk menjamin terpenuhinya hak-hak istri dan anak pasca terjadinya perceraian. Dari alasan-alasan tersebut ditemukan beberapa faktor yang menjadi penguat adanya kebijakan ini. Faktor-faktor inilah yang mengakibatkan istri tidak mendapatkan hakhaknya setelah terjadinya perceraian. Adapun faktor-faktor yang melatar belakangi kebijakan majelis hakim di atas adalah sebagai berikut: Pertama, Faktor kebencian. Faktor ini adalah faktor paling mendasar yang menjadi sebab tidak terpenuhinya hak istri pasca perceraian. ${ }^{36}$

Kebanyakan kasus yang terjadi di Pengadilan Agama Mojokerto, karena suami yang membenci istrinya maka setelah perceraian terjadi suami tidak mau tahu dan tidak mau berurusan lagi dengan istrinya, hal ini tentunya berdampak pada pemenuhan nafkah istri setelah perceraian terjadi. Selain itu apabila istri membenci suaminya dan tidak bersedia untuk datang ke persidangan maka majelis hakim akan menjatuhkan putusan verstek dan istri tidak bisa untuk mengajukan gugatan balik (reconvensi) tentang nafkahnya karena tidak hadir di dalam persidangan.

Kedua, Faktor kemampuan ekonomi. Faktor ini menjadi faktor yang paling sering diajukan sebagai alasan gugatan cerai istri kepada suami, karena kebanyakan yang mengajukan perceraian banyak perempuan atau istri yang bekerja untuk membantu ekonomi keluarga, tetapi kemudian muncul suatu problem ketika pendapatan istri lebih besar dari suami atau bahkan suami yang pengangguran dan yang bekerja adalah istrinya, hal ini kemudian menimbulkan cekcok di dalam rumah tangga tersebut hingga terjadilah gugatan cerai. ${ }^{37}$

\footnotetext{
36 Ibrahim Ahmad Harun S.Ag., Pedoman Pelaksanaan, 48.

${ }^{37}$ Drs. H. Mulyani, M.H. W awancara tanggal 06/08/2017.
} 
Dalam beberapa kasus di Pengadilan Agama Mojokerto, terkadang ada istri yang memang sengaja meminta nafkah mut.ah dan idah yang secara logika melebihi batas kemampuan suaminya. ${ }^{38} \mathrm{Hal}$ ini dilakukan oleh istri untuk membebani suaminya, dan karena emosi suami menyanggupi gugatan nafkah dari istrinya yang pada akhirnya malah memperlambat proses perceraian. Apabila suami belum mampu menyediakan uang tersebut maka Pengadilan akan menjadwalkan ulang sidang pembacaan ikrar talak sampai paling lama 6 bulan sejak putusan dikeluarkan.

Ketiga, Faktor ketidaktahuan istri tentang hak-haknya. Dalam hal ini majelis hakim pada saat sidang berlangsung melalui hak ex-officio yang dimilikinya akan memberikan pengarahan kepada istri tentang hakhaknya setelah bercerai. Disamping itu hakim juga akan melihat kondisi ekonomi dari istri, apabila istri berekonomi menengah ke bawah hakim akan memintakan nafkah istrinya kepada suami dari istri tersebut di dalam sidang sebagai sebuah reconvensi (gugatan balik) agar dapat tercantum di dalam putusan. ${ }^{39}$

Seperti halnya dikatakan oleh Sunjoto Imron bahwa sebenarnya hakhak istri yang sudah dicerai telah diatur di dalam Undang-Undang Perkawinan dan Kompilasi Hukum Islam, namun masih banyak istri yang tidak mengetahui sehingga mantan suami dengan mudah melalaikannya. ${ }^{40}$

Keempat, Faktor proses eksekusi yang rumit dan mahal. Faktor yang terakhir adalah proses eksekusi yang rumit dan mahal menurut penuturan Sunjoto, kebanyakan mantan istri yang ingin mengajukan eksekusi akan mengurungkan niatnya dikarenakan proses dan biayanya yang mahal. ${ }^{41}$ Secara prosedur eksekusi nafkah adalah bentuk permohonan mantan istri kepada Pengadilan Agama untuk membantunya dalam meminta hak nafkahnya setelah terjadinya perceraian yang belum atau tidak diberikan oleh mantan suaminya.

\footnotetext{
38 Drs. H. Mulyani, M.H. Wawancara tanggal 06/08/2017.

39 Drs. H. Mulyani, M.H. wawancara tanggal 03/08/2017.

40 Sunjoto Imron, S.H. Panitera Pengadilan Agama Mojokerto Wawancara tanggal $31 / 08 / 2017$.

41 Sunjoto Imron, S.H. Panitera Pengadilan Agama Mojokerto Wawancara tanggal $31 / 08 / 2017$.
} 


\section{Tinjauan Fikih Dalam Menjamin Pemenuhan Nafkah Mantan Istri}

Hakim sebagai seorang yang bertugas mengadili, memeriksa, dan memutus perkara dituntut untuk dapat menerapakan aturan perundangundangan secara benar dan adil. Jika aturan hukum tidak ada maka hakim harus manggalinya, seperti disebutkan dalam pasal 28 ayat 1 yang menyebutkan bahwa hakim wajib menggali, mengikuti dan memahami nilai-nilai hukum dan rasa keadilan yang hidup dalam masyarakat. ${ }^{42}$

Adapun bentuk kebijakan yang ada di lingkungan Pengadilan Agama merupakan implementasi dari tugas pokok di atas di samping juga agar tercapainya mașlaḥah antara para pihak pencari keadilan. Adapun maslahah yang dapat tercapai dengan adanya kebijakan yang diterapkan oleh majelis hakim Pengadilan Agama antara lain: Kemaslahatan bagi istri yaitu nafkahnya terpenuhi, Kemaslahatan bagi suami yaitu kewajibannya secara agama dan Negara terlaksana, dan maslahat bagi anak yaitu nafkah anak hingga dewasa terjamin.

Berkaitan dengan maslạah ini Najm al-Din al-Ṭufi (675-716 H./12761316 M.), seorang ahli ușul dari Mazhab Hanbali mengatakan: bahwa inti dari seluruh ajaran Islam yag termuat dalam naṣ adalah mașlặah bagi seluruh umat manusia. Karenanya, seluruh bentuk ke- maslaḥah-an itu tidak perlu mendapatkan dukungan dari nas, baik oleh nas tertentu maupun oleh makna yang dikandung oleh sejumlah nas. maslaḥah menurut al-Ṭufi adalah dalil kuat yang secara mandiri dapat dijadikan alasan dalam menentukan hukum Shara. ${ }^{43}$

Dalam fikih klasik memang disebutkan bahwa nafkah idah dan mut'ah adalah karena sebab terjadinya perceraian, bukan menjadi syarat. Menurut Abu Hanifah nafkah-nafkah tersebut dianggap hutang yang resmi sejak hari jatuhnya talak. Hutang ini tidak dapat dihapus, kecuali sudah dibayar lunas atau dibebaskan.

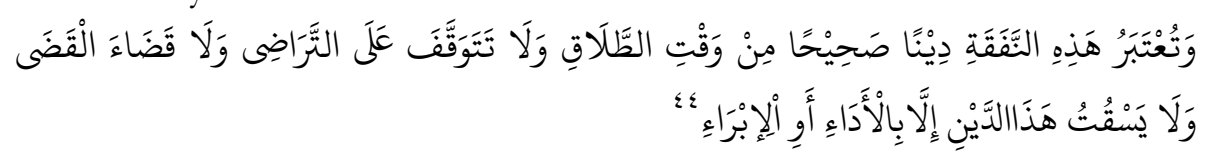

Artinya; "Dikatan babwa nafkah ini adalab butang sejak jatubnya talak, tidak dapat dihapuskan hanya oleh keridloan istri, ataupun dengan keputusan hakim, dan hutang tidak dapat berakhir kecuali apabila ditunaikan atau dibebaskan."

42 Undang-Undang No. 4 Tabun 2004 pasal 28 ayat 1.

${ }_{43}$ Nasrun Haroen, Ushul Fiqih (Jakarta: Logos, 1996), 124-125.

${ }^{44}$ Sayyid Sâbiq, Fiqbu al-Sunnab Vol. 2 (Kairo: al-Fath li al-A’lam al-Arabiy, 2003), 216. 
Di lingkungan Pengadilan Agama pemenuhan nafkah ini sangat minim sekali dilakukan oleh mantan suami ketika talak telah dijatuhkan. Apabila teknis pemenuhan nafkah tetap dijadikan sebagai akibat yang ditimbulkan dari adanya ikrar talak, maka dalam kasus di Pengadilan Agama ini syariat malah mempersulit pemenuhannya. Padahal menurut Ibnu al-Qayyim syariat islam itu dibangun untuk kepentingan manusia dan tujuan-tujuan kemanusiaan yang universal, yakni keadilan, kerahmatan, kemaslahatan, dan kebijaksanaan atau mengandung hikmah dalam kehidupan. Penyimpangan terhadap prinsip-prinsip ini berarti bertentangan dengan cita-cita syariat. Dengan demikian setiap hal yang zhalim, tidak memberi rahmat, dan tidak maslahah bukanlah hukum Islam. $^{45}$

Masih dalam kitab yang sama Ibnu al-Qayyim menyebutkan sebuah kaidah yang berbunyi:

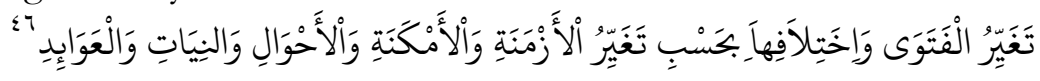

Artinya: "Babwasanya fatwa dapat berubah dan berbeda karena adanya perubahan waktu, tempat, keadaan, dan niat serta sesuatu yang terjadi kemudian."

Kaidah di atas dalam konteks kebijakan hakim dalam menghukum suami agar membayar nafkah sebelum ikrar talak juga bersesuaian dengan kaidah fikih berikut ini:

Artinya: "Kesulitan dapat menarik kemudahan." $" 7$

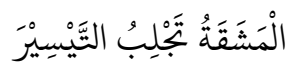

Lafal mashaqqah secara bahasa artinya adalah sulit (berat). ${ }^{48}$ dalam konteks kebijakan majelis hakim ini, mashaqqah-nya adalah beratnya pemenuhan nafkah istri setelah perceraian, sedangkan kemudahan atau keringanannya adalah pembayaran nafkah istri pasca cerai yang dilakukan sebelum ikrar talak.

\section{Penutup}

Dari pemaparan di atas dapat dipahami bahwa pemenuhan nafkah cerai istri itu boleh dibayarkan sebelum penjatuhan ikrar talak oleh suami,

\footnotetext{
45 Ibnu al-Qayyim al-Jawziyyah, I'lam al-Muwaqqi'in 'an Rabb al-'Alamîn, Vol. 1 (Beirut : Dâr Ibnu al-Jawziy, 2003), 41.

46 Ibnu al-Qayyim al-Jawziyyah, I'lam al-Muwaqqi'in, 41.

47 KH. M. Yahya Chusnan Manshur, al-Thamâratu al-Mardiyyah (Jombang: Pustaka AlMuhibbin, 2009), 71.

${ }^{48}$ KH. M. Yahya Chusnan Manshur, al-Thamâratu al-Mardịyyah, 71.
} 
dengan beberapa pertimbangan yaitu pertimbangan maslaḥah dan rubsah. Sehingga apabila diterapkan adalah sah menurut fikih.

\section{Daftar Pustaka}

Abdul Hamid, H. Ahsin. Komentar Terhadap Amar Putusan PA Takalar, dalam www.badilag.net diakses tanggal 07 April 2017

Asqalani (al), Ibnu Hajar. Bulughul Maram. Mesir: al-Matba'ah Salafiyyah, t.th.

Haroen, Nasrun. Ushul Fiqih. Jakarta: Logos, 1996.

Harun S.Ag., Ibrahim Ahmad. Pedoman Pelaksanaan Tugas dan Administrasi Peradilan Agama Buku II. Jakarta: Mahkamah Agung RI, 2013.

Imron, S.H. Sunjoto. Panitera Pengadilan Agama Mojokerto.

Jawziyyah (al), Ibnu al-Qayyim. I'lam al-Munaqqi'in 'an Rabb al-'Alamin. Beirut : Dâr Ibnu al-Jawziy, 2003. Vol. 1.

Kompilasi Hukum Islam

Manshur, KH. M. Yahya Chusnan al-Thamâratu al-Mardiyyah. Jombang: Pustaka Al-Muhibbin, 2009.

Mulyani, M.H., Drs. H. Hakim Pengadilan Agama Mojokerto.

Munawwir, A.W. Kamus Al-Munawnir Arab-Indonesia. Surabaya: Pustaka Progresif, 1997.

Rusyd, Ibnu. penerjemah: Imam Ghazali Said \& Achmad Zaidun, Bidayatul Mujtahid. Jakarta : Pustaka Amani, 2002. Juz 2.

Sâbiq, Sayyid. Fiqhu al-Sunnah. Kairo: al-Fath li al-A'lâm al-Arabiy, 2003. Vol. 2.

Syarbayniy (al), Muhammad al-Khathib. Mughniy al-Mubtaj. Beirut: Dâr alMa'rifah, 1997. Juz 3.

Syarifuddin, Amir. Hukum Perkawinan Islam di Indonesia: Antara Fiqh Munakahat dan Undang-Undang Perkawinan. Jakarta: Prenada Media, 2006.

Syarifuddin, Prof. Dr. Amir. Hukum Perkawinan Islam di Indonesia: Antara

Fiqh Munakahat dan Undang-Undang Perkawinan. Jakarta: Prenada

Media, 2006. Cet.3.

Undang-Undang No. 4 Tahun 2004 pasal 28 ayat 1.

Undang-Undang No. 7 tahun 1989

Undang-Undang Republik Indonesia No. 1 Tahun 1974

Yayasan Penyelenggara Penterjemah al- Qur'an DEPAG RI Al-Qur'an dan Terjemahnya, Jakarta: Depag RI, 2009. 
195 Syaiful Hidayat - Pemenuhan Nafkah Mut'ah, Iddah, Dan Madlyah Istri Sebagai Syarat Penjatuhan Talak 